\title{
LMIED EDION
}

Prints from the Original Oils of Award Winning Artist H.T. BECKFR



\section{$\mathbb{B}_{y} \mathcal{J}_{\boldsymbol{L} \varepsilon} \mathcal{L}_{\varepsilon \cup \varepsilon \varepsilon}$}

Image Size $15 \times 23$

Print Only

$\$ 72.00$

Framed

$\$ 174.00$

H.T. Becker's work is perceptive and clear. He uses luminescent techniques that seem to spread a diffused light over the surface of the painting. This combined with the realism in which

his work is created evokes a haunting quality. Mr. Becker has won numerous awards and his works are in public and private collections nationally and abroad. Editions limited to 950 signed and numbered by the artist. Printed in full color.

To order, please send your check or money order to:

First Impressions, 6900 Grove Road, Thorofare, New Jersey 08086

(N.J. residents add $6 \%$ sales tax.) 


\section{WHAT'S THE BEST HANDWASH/SCRUB? HANDS UP OR HANDS DOWN IT'S}

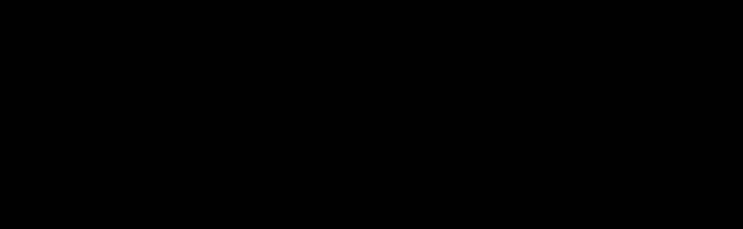

It is well established that handwashing is the most important single procedure in preventing transmission of hospital-acquired infections. HIBICLENS, the only proven antiseptic/antimicrobial, is the best agent available for both personnel handwashing and surgical scrubbing. HIBICLENS provides the most immediate and prolonged protection against infection, with the best bactericidal "kill rate." And to encourage skin cleansing among hospital personnel, HIBICLENS offers cosmetic acceptability coupled with an excellent safety profile. Gentle to the skin, HIBICLENS is virtually nonirritating and nonsensitizing, with a low potential for toxicity.

Available as both a liquid and impregnated in a disposable Sponge/Brush, HIBICLENS remains the single most effective antiseptic/antimicrobial skin cleanser for use throughout the hospital.

\section{THE BEST ANTISEPTIC/ANTIMICROBIAL SKIN CLEANSER}

